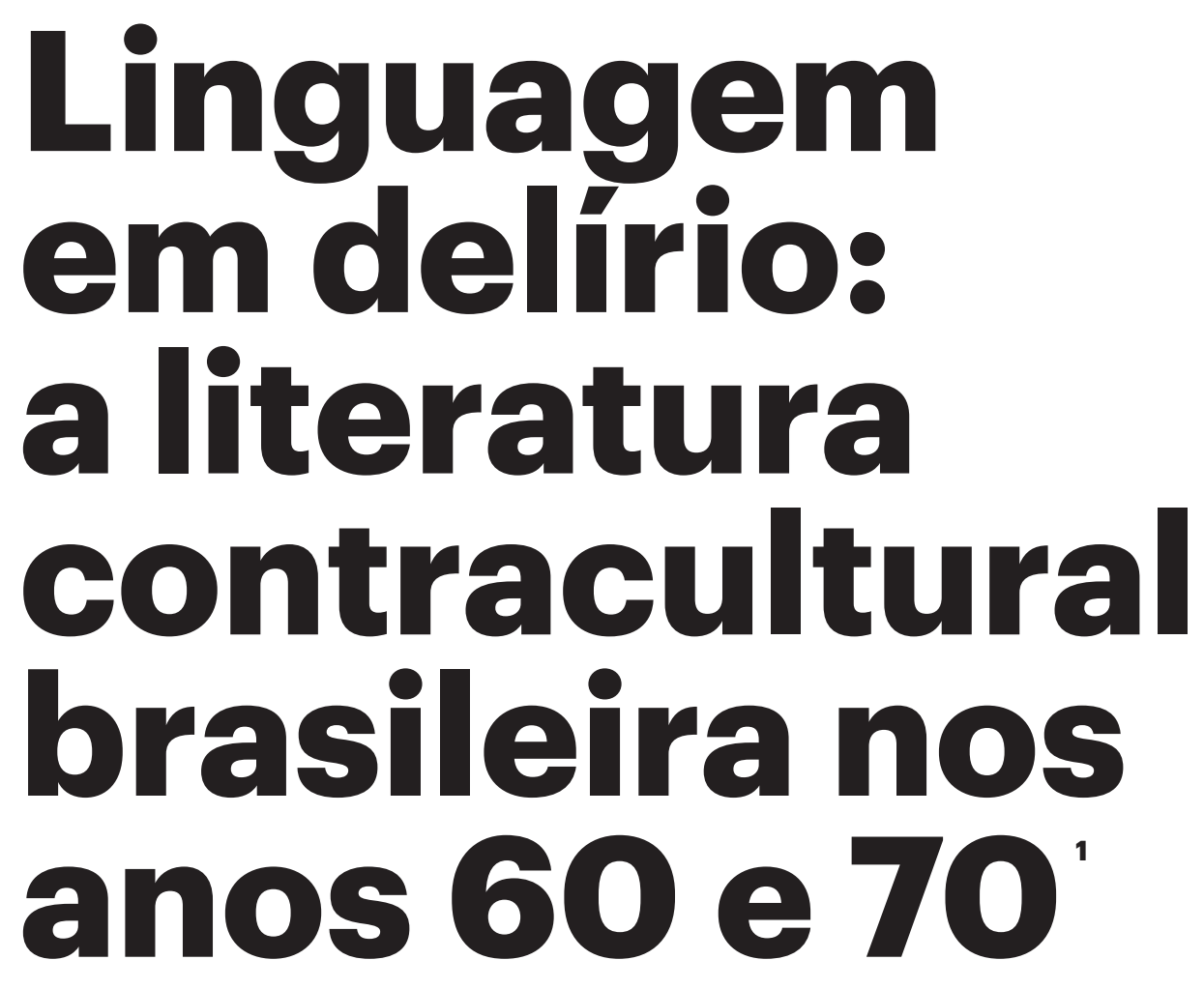

\section{André Masseno}

Romanisches Seminar

Universität Zürich

- andre.masseno@rom.uzh.ch

Dol https://doi.org/10.34913/

journals/lingua-lugar.2020.e212
1 O presente artigo é uma versão expandida e revisada da comunicação "Visões alucinadas: narrativas e literatura brasileira anos 60/70", apresentada no colóquio "Modelos e desvios. Transgressão de géneros em culturas de língua portuguesa", organizado pela Prof. ${ }^{\text {a Dr. }}{ }^{\text {a Maria }}$ Ana Ramos e realizado durante os dias 24 e 25 de maio de 2019 na Universität Zürich (UZH). O colóquio foi uma iniciativa da Cátedra Carlos de Oliveira (Camões IP), então dirigida pela Prof. ${ }^{a}$ Dr. ${ }^{a}$ Maria Ana Ramos, e contou com os apoios do Programa de Doutorado do Romanisches Seminar da Universität Zürich (Rom+) e da

Conferência Suíça de Escolas Universitárias (SHK). 
Durante os anos 60 e 70 quando o Brasil vivia os anos mais acirrados da ditadura, uma série de narrativas literárias apresentava um olhar crítico para o período vigente. Certa parcela de autores afinados com a contracultura buscava uma abordagem da realidade sociopolítica nacional a partir de ficções repletas de imagens alucinógenas/alucinadas. Partindo deste contexto, o presente artigo busca assinalar algumas produções literárias interessadas na abordagem daquele momento brasileiro através do que cunhamos como experiência do delírio, apresentando uma linguagem multifacetada que, por sua vez, desmantela a logicidade e o controle discursivo almejados pelos meios oficiais.

Palavras-chave: literatura; anos 60-70; Brasil; contracultura.

Au cours des années 1960 et 1970, alors que le Brésil vivait les années les plus difficiles de la dictature, une série de récits littéraires a présenté un regard critique sur le régime instauré. Plusieurs auteurs branchés sur la contre-culture ont cherché à approcher la réalité sociopolitique nationale à partir de fictions regorgeant d'images hallucinogènes/hallucinées. Partant de ce contexte, notre article tente d'analyser quelques productions littéraires motivées par l'approche de ce moment brésilien à travers ce que nous qualifions d'expérience du délire : elles présentent un langage à multiples facettes qui, à son tour, démantelle la logique et le contrôle discursif requis par les milieux officiels.

Mots-clefs: littérature ; années 1960-70 ; Brésil ; contreculture 
$\mathrm{Na}$ crônica "Literatura e justiça", Clarice Lispector pergunta-se a respeito de sua duvidosa inaptidão para aproximar-se de "modo literário" da "coisa social" (Lispector, 1979, p. 25), manifestando um misto de dor e humilhação por não lograr tal intento: ${ }^{2}$

\footnotetext{
2 Dizemos "duvidosa inaptidão", já que certas obras da autora, tais como A hora da estrela e a crônica "Mineirinho" - se levarmos em consideração estes poucos exemplos - revelam a proeza de Lispector na reescritura literária das tensões sociais de seu tempo.
}

Muito antes de sentir "arte", senti a beleza profunda da luta. Mas é que tenho um modo simplório de me aproximar do fato social: eu queria era "fazer" alguma coisa, como se escrever não fosse fazer. O que não consigo é usar escrever para isso, por mais que a incapacidade me doa e me humilhe. (Lispector, 1979, p. 25)

A autora brasileira encena uma certa vergonha por não se sentir uma contribuinte efetiva para ações na esfera social através da escrita literária, embora não se penitencie por tal incapacidade. Podemos tomar o dilema de Clarice Lispector como alegoria de toda uma geração de escritores brasileiros desde o início dos anos 60, passando pelo primeiro momento da ditadura no Brasil em 1964 até final da década de 70, quando o regime autoritário começava a dar sinais de falência e surgia uma abertura política, lenta e gradual, rumo à democracia. Em uma época marcada por uma frente artística "engajada" - vide a existência do Centro Popular de Cultura (CPC), criado em 1962 por um grupo de intelectuais de esquerda, em aliança com a União Nacional dos Estudantes, a fim de promover uma relação entre arte e política através de um forte apelo pedagógico-didático, mas vindo a ser desmantelado pela ditadura em 1964 - a escrita de Clarice Lispector era comumente lida como nada "participativa", pelo menos explicitamente. A (auto)cobrança de um posicionamento político e do comprometimento da arte com a situação sociopolítica daquele momento produzia uma tensão no campo literário que, muitas vezes, buscava abordar criticamente a realidade brasileira, inclusive tentando suprir a parcialidade de discursos oficiais que escamoteavam os resultados de sua maquinaria opressora.

O contexto ditatorial brasileiro é um velho conhecido, contudo precisamos aqui, de forma breve, novamente retomá-lo: durante os primeiros anos da ditadura, o espaço citadino no Brasil caracterizou-se pela ocorrência de manifestações populares contrárias ao regime militar. A partir do recrudescimento dos protestos após a implementação do Ato Institucional número 5 (Al-5) em 13 de dezembro de 1968, instaurou-se a experiência do medo e o silenciamento dos civis. A mobilização política popular nos centros urbanos sofreria abalos profundos, culminando 
com a desarticulação dos movimentos estudantis e perseguição de seus integrantes, então considerados subversivos. A literatura, portanto, tornar-se-ia um dos alvos principais da censura. Por conseguinte, autoras e autores buscavam formas de driblar o procedimento censório, culminando em propostas literárias que abordavam o contexto político de forma enviesada. Com isso, a literatura precisou lançar mão de certa "acrobacia linguística", como assinalou Zuenir Ventura:

Poucas vezes a língua portuguesa terá dado tantas voltas para sugerir o que não pode dizer e insinuar o que não pode revelar. O que economizaram em partículas negativas e adversativas, a arte e o jornalismo esbanjam em metáforas, elipses, eufemismos, perífrases, antíteses, circunlóquios, para dizer que o rei está nu, ou melhor, para insinuar que estaria [...]" (Ventura, 2000, p. 58 - grifo de Ventura).

Ainda de acordo com o autor, "o [tempo verbal do] condicional, com seu (mau) caráter duvidoso e ambíguo de tempo e modo, é um atenuador que permite dizer sem afirmar, informar sem se comprometer e rejeitar sem dizer não" (Ventura, 2000, p. 58).

Cabe lembrar que o drible linguístico não fora uma premissa adotada por todos os autores, já que algumas obras optaram por desviar-se de tal estratégia. Um caso exemplar de desvio foi o do romance-reportagem, um procedimento literário que, apesar dos limites da censura exercida sobre as produções culturais, aliava traços do romance policial e do registro documental em meados da década de 70 , chegando alcançar um grande número de vendagens. ${ }^{3}$

3 Seria o caso do escritor José Louzeiro com os romances Lúcio Flávio, o passageiro da agonia (1975), Aracelli, meu amor (1976) e Infância dos mortos (1977).

Contudo, entre os anos finais da década de 60 e meados da subsequente - ou seja, em um momento anterior ao romance-reportagem -, uma certa parcela da produção literária permaneceu apartada tanto da "acrobacia linguística" quanto da denúncia direta ao contexto nacional, além de lidar de forma diversa com a tensão entre produção artística e posicionamento político. Em vez de trilharem o caminho da denúncia direta ao contexto nacional, alguns autores investiram mais precisamente no campo da linguagem, gerando uma escrita literária calcada na encenação e na produção da experiência do delírio e da desmesura. Estas obras, portanto, contrapunham-se ao efeito de logicidade discursiva então almejada pelos equipamentos culturais e de propaganda atrelados ao Estado autoritário, por sua vez centrado nos aspectos discursivos de coesão e de univocidade em prol do desenvolvimento de uma ética nacionalista e de fundo coercitivo. A linguagem tornava-se acionadora de realidades 
alternativas e contrapostas ao discurso oficial. Eram produções literárias escritas por certa leva de jovens autores ainda não consagrados pelo panteão literário e geralmente afinados com o movimento contracultural que então aportava no Brasil. Estes autores almejavam formas alternativas tanto na linguagem quanto no modo de difundir suas produções, com isso criando brechas ao longo de um período repressivo nacional que logo seria denominado como os "anos de chumbo" (1968-1974). Suas obras trariam à cena diversos aspectos então alheios ao meio literário canônico, pondo-o em diálogo com a linguagem visual-midiática dos produtos culturais de massa, com as experiências típicas da juventude do período (a linguagem cotidiana dos jovens, o consumo do rock'n'roll e de drogas lisérgicas, leituras de teor esotérico, a filosofia hippie, a vivência em coletividade) e com elementos da arte pop. Nas franjas do campo literário, uma nova sensibilidade surgia através de uma geração jovem e de mirada cosmopolita, "antenada" com a contracultura e, segundo Silviano Santiago, pouco afeita "[ao] que se chama o lado castiço da linguagem do escritor" (Santiago, 2019, pp. 158-159).

Estes dados comprovam, em retrospecto, a insistência de uma literatura contracultural brasileira, que habitaria as franjas do meio literário durante as décadas de 60 e 70, desdobrando suas características estéticas e éticas nos decênios posteriores. Desta gama de produções literárias contraculturais, de amplo espectro e repletas de particularidades, pretendemos nos debruçar sobre algumas obras que, a nosso ver, investiram argutamente em uma linguagem que desmantelasse a primazia do logos, optando pela produção de uma experiência do delírio, portanto distanciada da racionalidade e afinada com as vivências lisérgicas. Não se trata, contudo, de exemplos exaustivos, ${ }^{\mathbf{4}}$ mas sim de uma pequena seleção de obras cuja especificidade de sua abordagem sobre o momento brasileiro se deu tangencialmente ao apostarem em uma linguagem do delírio, gerando, com isso, visões alucinadas sobre a realidade. São obras relevantes deste "legado literário contracultural" e que, a nosso ver, ainda merecem a devida e continuada atenção por parte da crítica especializada. Neste sentido, o presente artigo pretende modestamente contribuir para a redução desta lacuna.

\footnotetext{
4 Não exaustivo porque iremos ater-nos ao registro da prosa, não contemplando aqui a produção poética, como, por exemplo, a poesia marginal do início dos anos 70, que foi uma das produções cruciais para a evidência de formas alternativas de comportamento social, e principalmente de produção e de difusão do produto literário na esfera sociocultural brasileira. Para uma abordagem sobre a poesia marginal, cf. Ferraz, 2013.
} 


\section{A linguagem do delírio}

Uma das obras prenunciadoras da narrativa literária contracultural é o romance Deus da chuva e da morte, publicado em 1962 por Jorge Mautner. Bem antes da consolidação do regime ditatorial, Mautner propunha uma obra que, em mais de 300 páginas, se compunha de vários episódios que podem ser lidos separadamente como breves contos, e muitas vezes reescritos incansavelmente, elaborando uma mescla entre autobiografia, narrativa metaliterária, relatos de experiência mística, debate histórico-político e enredo mítico-lendário. Deus da chuva e da morte apresenta uma linguagem dispersiva e prolífera, não necessariamente marcada pela coesão e logicidade como elementos convergentes para a atenção do leitor. Uma das características significativas da obra de Mautner reside na abordagem de um imaginário pertencente a uma parcela da juventude já predisposta à vivência contracultural, que se consolidaria ao longo das décadas de 60 e 70. Este argumento se atesta pelo apelo da obra a uma linguagem delirante, remetendo às experiências lisérgicas, além de conjugar dois aspectos espaciotemporais: um incansável procedimento associativo de imagens em cadência rítmica e a recorrência ao movimento cíclico de retomada de certos acontecimentos narrados - aspecto que se tornaria uma espécie de marca autoral de Mautner e desdobrada no romance seguinte, Kaos, publicado em 1964. Contudo, fiquemos com um exemplo de Deus da chuva e da morte:

[...] fui andando na noite e a noite estava chuvosa e de repente eu me vi numa estrada de rodagem. E não me digam mas de repente em frente de uma árvore eu vi dançando, requebrando, chacoalhando um Rock-blue de Natal cujo nome é Santa Claus is back in Town o Arthur de Mello Guimarães todo frenético e molhado e suado, seus cabelos de ouro eram cabelos de Natal e ele não me viu, não ligou para mim, continuou a dançar e eu me espantei todo. Será que era uma noite mágica? [...] Ele era o Dionísio do Natal? Será! [...] O Arthur ficou sozinho comigo e a chuva caía. Depois nós fomos andando lentamente pelos montes enchuvarados e lentamente a manhã foi nascendo. Ouvia-se pelo ar a Noite Feliz cantada pelo Elvis, não sei daonde, não sei porque, vai ver era nossa febril imaginação já atingindo as raias do desespero pois Arthur também ouvia Silent Night cantada pelo Elvis e a chuva parou e eu olhei para uns postes lá embaixo molhados e com pingos que nem pérolas agarradas nos fios pretos e Arthur também olhou e alguns passarinhos pousaram nos postes e nos fios com pérolas. (Mautner, 2002, pp. 228-229)

No episódio acima, o leitor é confrontado com uma narrativa que se assemelha a um fluxo contínuo de pensamento, que incansavelmente descreve fatos e espacialidades a ponto de gerar uma experiência delirante. 
As referências culturais frequentes em Deus da chuva e da morte, de aspecto cosmopolita e afinadas com a cultura de massas, revelam o denominador comum de uma produção literária que se distancia da cultura nacional institucionalizada, por sua vez preocupada pela manutenção de um visão essencialista do Brasil e de suas expressões culturais. Além disso, há um efeito rítmico na narrativa semelhante ao fluxo da fala coloquial e, muitas vezes, repleta de fôlego, o que pode ser verificado pela supressão do emprego da vírgula em certas passagens mais extensas. Tal condição "irrespirável" da fruição de Deus da chuva e da morte contribui para o estabelecimento de uma linguagem delirante, principalmente quando aquela é emparelhada com uma rede associativa de imagens, que se apresenta ininterrupta e supostamente destituída de critérios rígidos para a seleção dos fatos a serem narrados. Logo, a linguagem delirante da obra de Mautner, rítmica e imageticamente incansável, fratura qualquer possibilidade de circunscrição categórica de seu foco narrativo, que anseia escapar das formas estritamente literárias, ao mesmo tempo que deseja um espaço escritural mais próximo de uma experiência vital.

Quase uma década depois ocorria a estreia literária de Gramiro de Matos com o romance Urubu-Rei (1972), com o subtítulo de "montagem d'alquimia chiclete do milênio/ celefos/ tupã-guaraná". Lançada quando o movimento contracultural estava assentado no Brasil - período marcado pela contribuição de Torquato Neto na coluna "Geleia Geral" no Última Hora, pelos textos do "guru da contracultura" Luiz Carlos Maciel em O Pasquim e pelo advento da "poesia marginal" -, a obra de Gramiro de Matos chegou inclusive a ser analisada à época por críticos literários como Silviano Santiago, que o aproximou da produção poética do então estreante Wally Salomão com o livro Me segura q'eu vou dar um troço (1972), cunhando as obras de ambos os autores como "hipóteses de uma linguagem que se quer constantemente lúdica e livre, sem as peias do dicionário e da gramática" (Santiago, 2019, p. 168).

Assim como a obra de Jorge Mautner, Urubu-Rei investe em uma experiência rítmica da linguagem. Contudo, na obra de Gramiro de Matos tal experiência afilia-se à adoção de neologismos que ressignificam a língua portuguesa como idioma moldável, além de aglutinar o vocabulário indígena e torcer sintaticamente o português a partir de seu confronto com a sintaxe tupi. A obra compõe-se de fragmentos que jogam com as possibilidades do espaço em branco de cada página, instigando uma experiência de leitura que conjumina ilustração e escrita, sem optar completamente por uma relação descritiva e complementar entre 
ambas. Gramiro de Matos instaura um mundo de performances vocais, propondo uma escrita cuja plasticidade convida a leitura em voz alta, transbordando a letra impressa:

e o gongo comeu a mão miau miau comeu o gongo
a mão a mão a mão a mão a mão a mão o gongo comeu
o gongo comeu o gongo comeu o gongo comeu o gongo
comeu comeu comeu comeu comeu comeu comeu o gon-
go o gongo o gongo o gongo o gongo ogongo ogongo
miau miau miau miau a mão amão a mão de você é lus-
parindo mas mas mas mas mas mas mas mas mas mas
max maw mak gás gás gás gás gás gás gás gás gás gás
gás gás gás o gongo comeu fas fas fas fas fas fas fas fas
fas miau miau a mão a mão a mão pas pas pas pas pas
pas pas pas pas pas pas pas pas mas mas mas mas maw
mak miau mais ontonce o mundo diabobou? (Matos, 1972, s.p.)

A linguagem é construída através de uma série (fonética e sintaticamente) rítmica e repetitiva, transformando a literatura em um jogo performático que extrapola os limites da escrita, exigindo a participação da fisicalidade do leitor. Assim, a linguagem literária torna-se um recurso convidativo para a "curtição", isto é, para uma experiência que conjuga uma nova sensibilidade comportamental-estética e estado de inventividade, deslocando o leitor do automatismo linguístico presente na linguagem diária (cf. Santiago, 2019, p. 153).

O convite de Gramiro de Matos a uma leitura desautomatizada ainda prevalece em Os morcegos estão comendo os mamões maduros (1973), obra que, assim como Urubu-Rei, recebera pouca atenção crítica. A escritura radicaliza o uso da linguagem a partir de uma estética de montagem, na qual convergem textos diversos extraídos dos meios de comunicação, lendas indígenas e expressões orais pertencentes ao cotidiano urbano brasileiro. Como o próprio autor afirma na introdução do livro, "[as] histórias não têm sumário, pois não tem fim nem princípio", tratando-se de "transformações limitadas que tenta (sic) uma narrativa ligada à atividade mental variável - não apenas uma linguagem que apresente o mundo, mas a metamorfose do mundo inconsciente em movimento" (Matos, 1973, p. 7). Ocorre, portanto, a variação das formas mentais em ato de escritura e que flerta com o fluxo de realidades que escapam de qualquer procedimento descritivo. Em certos momentos, a obra retoma livremente o vocabulário tupi-guarani em reconfiguração paralela da sintaxe da língua portuguesa, além de usar o portunhol como língua torcida e impura, permitindo a criação de outras palavras e, por conseguinte, de outras realidades. Referências à contracultura brasileira 
estão impressas na obra, como a praia e a mata como espaços misteres da vida alternativa daquelas décadas:

\begin{abstract}
Mata sertão arrebenta o Besta viveu entre sicranos nos mangues dos trópicos latinos y pantanos d'areia-mulata, desbundou-se co'sabedoria dos camponeses mar i pescadores i vermelhos i cação, dia-a-dia, na estrada da vida novamente o desconhecido, visagem pelas av. dos cedros y assobração matarias fechadas xistosas y mutucas $k$ enchia y chupava seu tumor solifão maligna mosaico in-distinguia o caminho do real i o extra. (Matos, 1973, p. 53)
\end{abstract}

A literatura torna-se espaço e estopim do delírio, tornando-se uma das realidades possíveis e opostas ao discurso essencialista, racional e unívoco difundido pelo regime autoritário. O importante aqui era promover uma performance escritural, isto é, escritas literárias e de vida que pudessem empurrar a linguagem rumo à materialidade (do signo) como experiência, como afirma a voz narrativa de Os morcegos estão comendo os mamões maduros: "ser autor cantor ator poeta não ser categoria nem classificação ser ação outra questão não mais o ser sem o signo" (idem, p. 22). Seria, portanto, a materialidade de uma mutação sígnica e incansável, fruto de uma linguagem delirante que, por sua vez, busca o assentamento de um espaço literário composto pela devoração de espacialidades, de referências culturais diversas, de sintaxes e vocábulos alheios. Este movimento ininterrupto de deglutição, também presente em Deus da chuva e da morte de Jorge Mautner, parece guardar semelhanças com o "apetite antropofágico" de Oswald de Andrade, cuja obra havia sido redescoberta no final da década de $60 .^{\mathbf{5}}$ A devoração ilimitada de diversos substratos culturais resultava do desejo dos escritores afinados com a contracultura por uma narrativa inclusiva e que permitisse experiências de linguagem e leitura fora do senso comum.

Outra obra importante do período é a Panamérica, de José Agrippino de Paula, publicada em 1967, isto é, cinco anos antes de Urubu-Rei. Partindo de uma narrativa que remete à temporalidade de um roteiro cinematográfico, Panamérica é uma escrita "de fôlego" - novamente aqui o ritmo como elemento constitutivo

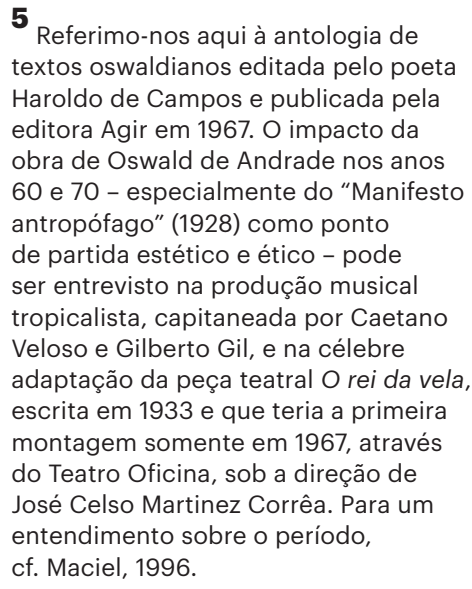

5 Referimo-nos aqui à antologia de textos oswaldianos editada pelo poeta Haroldo de Campos e publicada pela editora Agir em 1967. O impacto da obra de Oswald de Andrade nos anos 60 e 70 - especialmente do "Manifesto antropófago" (1928) como ponto de partida estético e ético - pode ser entrevisto na produção musical tropicalista, capitaneada por Caetano Veloso e Gilberto Gil, e na célebre adaptação da peça teatral O rei da vela, escrita em 1933 e que teria a primeira montagem somente em 1967, através do Teatro Oficina, sob a direção de José Celso Martinez Corrêa. Para um entendimento sobre o período, cf. Maciel, 1996. de uma linguagem delirante - devido à voracidade das imagens incansáveis e de nuances lisérgicas, saltando diante dos olhos do leitor. A obra é composta por um narrador em primeira pessoa e multifacetado, sendo ora integrante de um universo de personagens 
pertencentes ao mundo cinematográfico hollywoodiano da primeira metade do século $X X$, ora um guerrilheiro em fuga pelo território latino-americano. Aqui vamos nos ater à abordagem que Panamérica empreende do espaço da praia como lugar de delírio e de caos, de prazer hedonista e de conflitos políticos. No caso brasileiro, trata-se de uma obra pioneira na representação da praia como um dos espaços misteres da contracultura brasileira - e que também estaria presente nas obras subsequentes de Gramiro de Matos, Jorge Mautner e especialmente na produção poética de Ricardo Chacal, que surgiria no início dos anos 70 com Muito prazer, Chacal, um livro mimeografado feito à mão pelo próprio autor, que o vendia entre os banhistas da Praia de Ipanema, no Rio de Janeiro. Neste período, a praia tornar-se-ia o locus central de exercício da contracultura, apresentando-se propícia à experiência de uma nova política de viés contracultural e majoritariamente liderada por jovens que se opunham ao status quo. A praia abrigava uma juventude bastante atenta à arte pop e ao rock'n'roll, além de pouco afeita às relações políticas com os movimentos partidários de contestação e tampouco interessada pelos movimentos de guerrilha, que abrigaram certa parcela da juventude desesperançada pelos modelos partidários vigentes.

Em Panamérica, o espaço praieiro é um dos pontos centrais não somente da narrativa, mas também da elaboração do suporte livro de sua primeira edição, que fora impressa em folhas amarelas para que o leitor não fosse afetado pelos reflexos solares ao lê-lo na praia. Esta preocupação pela recepção denota o endereçamento de Panamérica a um leitor em potência, isto é, a um sujeito frequentador do espaço praieiro, e a sugestão de um possível espaço ideal para a fruição de uma obra cuja certa parcela do enredo se situa na região litorânea e na paisagem praieira. Portanto, a experiência da leitura literária não estaria apartada da vivência de espacialidades afinadas com o modo de vida contracultural.

Ao longo da primeira parte da obra, o narrador relata suas relações amorosas com a atriz Marilyn Monroe. Na descrição de um de seus encontros, ambos estão deitados na areia. A incidência da luz solar e a imagem marítima inebriante agem sobre o narrador e seu modo de olhar para a atriz. A praia possui um aspecto descomunal que o olhar do narrador prontamente transfere à Marilyn, conferindo-Ihe um rosto monstruosamente imenso:

A minha cabeça estava inclinada e eu via o rochedo como uma enorme massa de carne imóvel se introduzindo na água do mar [...]. A imensa massa líquida verde continuava enviando lentamente a série de pesadas ondas que se aproximavam do rochedo. Eu olhava para as pedras que 
pareciam ter uma consistência pastosa e pareciam ter sido jogadas do alto. Depois o rosto de Marilyn Monroe estava muito próximo do meu e a pele branca irradiava a luminosidade do sol [...]. Eu sentia a mesma desproporção da natureza, e o rosto de Marilyn Monroe iluminado pelo azul do céu, e eu via as dimensões gigantescas da boca, do nariz, e dos olhos fechados (Paula, 1988, p. 63).

Um inclinar de cabeça, conjugado com a praia luminosa e solar, modifica o olhar e as escalas. A luminosidade do espaço praieiro altera o estado de consciência, transformando a perspectiva e a percepção visual de seus frequentadores. Ocorre uma experiência alterada semelhante às lisérgicas e que permite uma certa relação de amálgama entre o sujeito e o entorno, adquirindo ambos um mesmo aspecto de massa carnal. Há uma espécie de indiferenciação e mutabilidade das formas, que oscilam entre uma massa ora de carne e imóvel, ora movente e líquida e, por vezes, pastosa. Concomitante a esta irradiação de luminosidade promotora de uma mutação corporal próxima às formas desproporcionais e ao gigantesco, paisagem e sujeito adquirem certa densidade partilhada. Isto pode ser atestado em um trecho posterior, quando o narrador e Marilyn fazem sexo dentro da água do mar: "[...] eu e ela permanecemos fatigados e imóveis, um preso ao outro no centro do mar, e ao longe a curva da praia, a estrada, a ponte, as montanhas, as nuvens brancas e brilhantes, a pequena ponte, a ilha, e o mar plano" (Paula, 1988, p. 210). Os corpos de Marilyn Monroe e do narrador fundem-se e, por conseguinte, misturam-se com a paisagem. A mescla entre os corpos das personagens e o espaço praieiro instaura a incerteza sobre a existência de uma realidade a ser relatada. Neste sentido, o que se evidencia é o estado delirante da voz narrativa, cuja sensibilidade alterada filtra constantemente o entorno. Os exemplos acima comprovam que Panamérica possui o compromisso com uma representação do real fundamentada mais sobre o princípio do prazer do que sobre o princípio da realidade (cf. Hoisel, 1980, p. 15), sem estar necessariamente marcada pela descrição fidedigna dos fatos. O que está em jogo é a instauração de uma fala do desejo sem culpa ou controle (Paula, 1988, p. 129), sendo o registro do delírio a contribuição imprescindível para o estabelecimento desta produção discursiva.

Entretanto, Panamérica não se limita a apresentar a praia como espaço hedonista, especialmente quando a narrativa passa a referir-se ao espaço praieiro em territórios latino-americanos. Neste caso, a praia transforma-se em palco da luta armada em confronto com as forças do Estado autoritário, ocasionando a fuga popular: "O povo gritava e todos corriam em pânico para a praia e entravam no barco dos pescadores. Os barcos cheios de homens, mulheres e crianças se afastaram da praia [...]" (Paula, 
1988, p. 107). A praia torna-se o acesso ao mar, então sugerido como possível território de escape da população diante das atrocidades locais. Aliada a esta imagem, o espaço praieiro apresenta-se dominado pela ação violenta dos equipamentos oficiais contra os movimentos de resistência. Exemplar é o episódio em que o narrador, já em condição de guerrilheiro em terra venezuelana e dentro de um sobrado à beira-mar, metralha os policiais que se encontram na praia:

Um grupo de nove policiais armados empurrava os pescadores na praia e eu atirei uma rajada de metralhadora. Quatro caíram e os cinco policiais correram em pânico na praia. Eu continuei metralhando os que fugiam em pânico e derrubei outros quatro, e o último entrou na mata e desapareceu entre as árvores. (Paula, 1988, p. 147).

Conforme a passagem acima, a praia em Panamérica é também campo de conflitos políticos e de opressão, representando o lugar da natureza onde se extingue o discurso libertário, ou a sua possibilidade de permanência quando um regime autoritário está em vigor. O romance de José Agrippino de Paula sugere a praia como espaço tanto de encenação de delírios díspares quanto de proliferação de discursos oficiais e de resistência. A praia configura-se como espacialidade onde são desfeitos os limites entre a experiência hedonista do mundo e a das atrocidades empregadas por um poder estatal autoritário. Neste sentido, Panamérica é uma obra que ficcionaliza não somente o delírio experienciado na vida contracultural, mas também a atuação dos governos repressivos "delirantes" dentro do âmbito latino-americano.

Na década posterior, outras obras surgem coabitando registros de delírio e sátira do contexto social, embora não estando associadas ao escopo da literatura contracultural. Uma delas é Zero, de Ignácio de Loyola Brandão, escrita em 1969 e censurada no Brasil, sendo publicada inicialmente em italiano e vindo a ser lançada em português somente em 1976. Com o subtítulo de "romance pré-histórico", o enredo é situado em algum lugar de uma "América Latíndia", onde se desenrola a vida de José, um sujeito qualquer e sem-valia, um "zero à esquerda" como diz a expressão em português, e que vive de eliminar ratos e baratas em um cinema decadente. O personagem é bombardeado tanto pelo universo pop quanto pela brutalidade policial. O romance compõe-se de estilhaços de narrativas visuais e escritas, reunidas conflituosamente no espaço da página. Nesta América Latíndia, assim como no aspecto narrativo de Zero, impera um caos total, no qual o delírio seria a face perversa de um espaço urbano dominado pela ditadura: 
Selva de asfalto - cidade desumana - metrópole voraz - comedora de gente - antro de neuróticos - túmulo de vidro - floresta de cimento armado - locomotiva puxando vinte vagões - o maior centro industrial da América Latíndia. (Brandão, 1980, p. 223)

Zero investe na encenação literária da "carnavalização da tirana", se quisermos parafrasear a expressão de Octavio lanni, cunhada ao analisar as produções literárias interessadas pela encenação da figura do ditador latino-americano (lanni, 1983). Para Malcolm Silverman, "Zero é uma descida inexorável e polimorfa a um inferno mais revoltante que o dos outros romances do período, influenciados, como eram, pelas convenções realistas" (Silverman, 2000, p. 360). Embora não esteja relacionada à produção contracultural, a obra de Ignácio de Loyola Brandão se aproxima daquela por investir em uma linguagem literária que encena e encarna o delírio. Assim como as produções de Gramiro de Matos, Zero rompe com a rigidez dos padrões linguísticos, lançando mão do uso indevido de vírgulas e da antecipação dos pontos finais no início das frases (cf. Lima, 2012, p. 92), além do emprego de grafismos que dividem a pluralidade da narrativa, distribuindo-a em espaços diversos da página tal como a diagramação usada em matérias de jornal. Em relação ao escopo narrativo, é preciso contudo fazer uma distinção: o delírio aqui apresenta-se impregnado de uma violência social, onde as desigualdades econômicas e de classe proliferam em um espaço citadino oprimido por um sistema autoritário e massificado pela enxurrada de informações acríticas provenientes dos meios de comunicação. Sob esta perspectiva, a precariedade das estruturas resultantes da modernização social acionam, na narrativa de Zero, uma vida repressivamente delirante e praticamente destituída do delírio de viés hedonista, apresentado pelas obras anteriormente analisadas.

Contudo, no final dos anos 70 , um novo panorama literário fora sendo delineado. A experiência do delírio adquirira outro matiz, através de escritas testemunhais empreendidas por exilados políticos que regressavam ao Brasil a partir do processo de abertura democrática. Tal literatura viria então, a partir de um discurso memorial ao calor da hora, recuperar e denunciar as atrocidades do governo vigente. Neste rol, podemos citar os célebres Em câmera lenta, de Renato Tapajós (1977), Quatro olhos, de Renato Pompeu (1978), O que é isso, companheiro?, de Fernando Gabeira (1979) e Os carbonários, de Alfredo Sirkis (1980). Em algumas destas obras, em de vez do delírio ser apresentado como experiência intrínseca à visada contracultural da vida, este seria assinalado como marca sobre corpos torturados por um sistema autoritário. O delírio, portanto, seria resultante de uma experiência fronteiriça e traumática - em suma, fruto 
de uma era dos extremos, onde loucura e razão perderiam suas bordas através do impacto da violência da tortura. Estas "escritas da tortura" - se assim quisermos empregar a expressão de Jaime Ginzburg (2012, p. 473) para denominar obras como a de Renato Tapajós, que elabora uma narrativa repleta de descrição de corpos torturados - desafiam as propostas sobre o delírio como aspecto constitutivo de uma linguagem alucinada, tal como empreendida pela literatura contracultural entre os anos 60 e 70. Logo, estamos diante de duas abordagens específicas da relação entre o delírio e um contexto externo fundado no autoritarismo e no controle das discursividades. Em linhas gerais, argumentamos que, por um lado, a literatura de testemunho pleiteava uma "literatura política", onde a violência era fundamento e tema, sendo o delírio um resultado de eventos traumáticos a serem denunciados; por outro, a produção literária contracultural optava por uma "política na literatura", onde o delírio se tornava elemento constitutivo e detonador da linguagem, que se transformava em arma jocosamente apontada para aquele momento histórico. ${ }^{\mathbf{6}}$

\begin{tabular}{l}
\hline 6 Consideramos relevante uma \\
abordagem arguta e aproximativa \\
destes dois períodos da produção literária \\
brasileira, que sempre foram vistos como \\
antagônicos. O delírio, seja como tema \\
ou como procedimento estopim para \\
produção de uma linguagem, pode ser \\
um aspecto a ser levado em consideração \\
para futuros estudos comparados sobre \\
ambas as produções.
\end{tabular}

Para concluir, inferimos que certa parcela da produção literária brasileira durante os anos 60 e 70 estava propondo o espaço do delírio no campo da linguagem como procedimento contestatório e promotor de outras camadas de uma realidade (neste caso, de um comportamento contracultural perante o mundo) que não configurava na agenda da cultura oficial. Se, por um lado, o investimento em uma linguagem calcada sobre o viés do delírio não é um procedimento exclusivo da literatura contracultural brasileira, por outro, as obras aqui analisadas desenvolvem, de forma radical, uma linguagem literária que põe em xeque os limites da racionalidade, além de desfazer os registros da coesão e da univocidade a partir de vozes narrativas extremamente plurais, multifacetadas. Em suma, o aspecto delirante da literatura contracultural é relevante devido à aproximação ficcional e contestatória do contexto brasileiro sob um regime totalitário, relevando ficcionalmente seu caos político e discursivo. 


\section{Bibliografia}

Brandão, I. de L. (1980) Zero. Rio de Janeiro: Matos, G. de (1972) Urubu-Rei. Rio de Codecri.

Janeiro: Edições Gernasa.

Ferraz, E. (2013) Poesia marginal: palavra e livro. São Paulo: Instituto Moreira Salles.

Ginzburg, J. (2012) Crítica em tempos de violência. São Paulo: Edusp.

Hoisel, E. (1980) Supercaos: os estilhaços da cultura em Panamérica e Nações Unidas. Rio de Janeiro: Civilização Brasileira; Salvador: Fundação Cultural do Estado da Bahia.

lanni, O. (1983) Revolução e cultura. Rio de Janeiro: Civilização Brasileira.

Lima, M. H. de. (2012) "Zero: uma alegoria do Brasil". Signótica, v. 23, jan./jun. 2012, pp. 87-101.

Lispector, C. (1979) “Literatura e justiça”. In: Para não esquecer. São Paulo: Ática, p. 25.

Maciel, L. C. (1996) Geração em transe: memórias do tempo do tropicalismo. Rio de Janeiro: Nova Fronteira.
- (1973) Os morcegos estão comendo os mamões maduros. Rio de Janeiro: Eldorado.

Mautner, J. (2002) "Deus da chuva e da morte" In: Mitologia do Kaos, vol.1. Rio de Janeiro: Azougue Editorial, pp. 9-349.

- Kaos. In: Mitologia do Kaos, vol.1. Rio de Janeiro: Azougue Editorial 2002, pp. 351-656.

Paula, J. A. de (1988) Panamérica. São Paulo: May Limonad.

Santiago, S. (2019) "Os abutres". In: Uma literatura nos trópicos. Recife, Cepe, pp. 149169 [1972].

Silverman, M. (2000) Protesto e o novo romance brasileiro. Rio de Janeiro: Civilização Brasileira.

Ventura, Z. (2000) Geração em trânsito. Rio de Janeiro: Aeroplano. 